\title{
Lactic Acid Bacteria Mediated Apoptosis Induction: Natural Way of Colon Cancer Cells' Inhibition ${ }^{+}$
}

\author{
Şebnem Kurhan ${ }^{1, *}$ and İbrahim Çakir ${ }^{2}$ \\ 1 Novel Food Technologies Development, Application and Research Center, Abant İzzet Baysal University, \\ Bolu 14280, Turkey \\ 2 Department of Food Engineering, Faculty of Engineering and Architecture, Abant İzzet Baysal University, \\ Bolu 14280, Turkey \\ * Correspondence: sebnemkurhan@ibu.edu.tr; Tel.: +90-374-254-1000 (ext. 4914) \\ + Presented at the 2nd International Conference on Natural Products for Cancer Prevention and Therapy, \\ Kayseri, Turkey, 8-11 November 2017.
}

Published: 10 November 2017

\begin{abstract}
Lactic acid bacteria, one of the members of human microbiome and gut microbiota, are known for their anti-carcinogenic properties. Apoptosis is a programmed cell death that can be named as "cell suicide". This physiological process has critical role in cancer treatments due to tumor formation is the result of the loss of apoptosis ability of the normal cells. Lactic acid bacteria mediated cancer treatment is related to the apoptosis induction in the cancer cells. In this study, we aimed to show the apoptotic effect of lactic acid bacteria named as Lactobacillus plantarum (responsible for plant based fermentations and probiotic bacteria) and Lactobacillus rhamnosus NRRL B-442 (probiotic bacteria and use in some specific dairy fermentations) in human colon adenocarcinoma cell line HT29. Apoptosis was determined two different methods: Acridine Orange-Ethidium Bromide Microscopic and Annexin V-Propidium Iodide Flow Cytometric assays. In flow cytometric assay necrosis was not detected. Results showed that the lactic acid bacteria used in the study leaded to apoptosis in HT-29 which is a colon adenocarcinoma cell line.
\end{abstract}

Keywords: apoptosis; Lactobacillus plantarum; Lactobacillus rhamnosus NRRL B-442

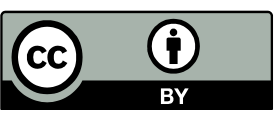

(C) 2017 by the authors. Licensee MDPI, Basel, Switzerland. This article is an open access article distributed under the terms and conditions of the Creative Commons Attribution (CC BY) license (http://creativecommons.org/licenses/by/4.0/). 